Acta vet. scand. $1986,27,313-325$.

From the Department of Cattle and Sheep Diseases, College of Veterinary Medicine, Swedish University of Agricultural Sciences, Uppsala, Sweden.

\title{
DISTRIBUTION OF PENICILLIN G IN SERUM AND TISSUE CAGE FLUID IN CATTLE*
}

\author{
By \\ Jan Luthman and S. O. Jacobsson
}

\begin{abstract}
LUTHMAN, JAN and S. O. JACOBSSON: Distribution of penicillin $G$ in serum and tissue cage fluid in cattle. Acta vet. scand. 1986, 27, 313-325. - The penetration of penicillin into tissue cage fluid (TCF) in calves was studied after intravenous and intramuscular injection. The penicillin concentrations in TCF were lower than in serum and maximum was reached much later. Intravenous injection of benzylpenicillin gave significantly higher levels in TCF than intramuscular injection. The penetration after procaine penicillin was very slow. The results showed that the serum peak rather than the area under curve determines the penetration of penicillin. Repeated intramuscular injections of benzylpenicillin and procaine penicillin caused an accumulation of penicillin in TCF. Similar levels were however reached by one single intravenous injection. The clinical counterparts to the used tissue cage model are abscesses. It was concluded that if high penicillin concentration are desireable in such foci, the drug must be given in a way that gives as high serum peaks as possible.
\end{abstract}

penetration; interstitial fluid; serum concentration.

The penetration of antibacterial drugs into the extravascular fluid is of vital importance for the therapeutic result. Several techniques have therefore been developed to make serial sampling of interstitial fluid and thus the study of drug penetration possible. The tissue cage technique has e.g. been used in laboratory animals (Carbon et al. 1977, Rylander et al. 1978, Tight \& White 1980), cattle (Stanton et al. 1982, Ziv et al. 1982, Luthman et al. 1984, and even man (Adam et al. 1978). In a previous study (Bengtsson et al. 1984) a tissue cage model for use in cattle was developed and evaluated. The most suitable cage model was made

* This investigation was supported by the Swedish Council for Forestry and Agricultural Research. 
of partly perforated silastic rubber tubing. The cages were implanted subcutaneously and after 2-3 weeks there was an ingrowth of granulation tissue through the perforations leaving a fluid filled space in the middle. Samples from this fluid, whose protein content is shown to be identical to that in peripheral lymph (Taylor \& Gibson 1975), are easily taken by means of a syringe and a fine injection neddle.

The penetration of drugs into tissue cage fluid (TCF) is influenced by several factors e.g. the open area of the cage, protein binding and ionization state of the drug (Bergan 1978). The shape of the serum concentration-time curve is another determinant. Bengtsson et al (1986) recently showed that intravenous injection of oxytetracycline gave higher concentrations in TCF than intramuscular injection of the same dose. Regardless of the way of administration there was a significant positive correlation between the area under curve (AUC) in serum and AUC in TCF, which is in accordance with results earlier published by Bergan (1978).

Penicillins are still the most used antibiotics in veterinary medicine and the aim of the present investigation was to study the penetration of penicillin $G$ into tissue cage fluid (TCF) in calves. Special attention was given to the influence of the serum concentration-time profile.

\section{Animals}

\section{MATERIAL AND METHODS}

Eleven calves of the Swedish Red and White breed were used. The animals were kept in individual pens and fed according to Swedish feeding standards.

\section{The tissue cage model}

The cages were made of silastic rubber tubing, with a length of $100 \mathrm{~mm}$, an inner diameter of $15 \mathrm{~mm}$ and an outer diameter of $21 \mathrm{~mm}$. About 80 holes $(3 \mathrm{~mm})$ were punched out at the ends of the tubes, leaving a $40 \mathrm{~mm}$ long unperforated middle piece. The ends of the tubes were sealed with silicone rubber plugs. The open area of the cage was about $30 \%$. All cages were autoclaved before use.

The calves were about 6 weeks old at the time of operation. The cages were implanted subcutaneously in the neck and flank regions as described by Bengtsson et al. (1984). 


\section{Drugs and drug administration}

The following drugs were used: Benzylpenicillin-K (Novocillin vet. $6.3 \mathrm{~g}$, Novo Industri $\mathrm{AB}$, Malmö), benzylpenicillin procaine (Penovet vet. $300 \mathrm{mg} / \mathrm{ml}$ Novo).

Benzylpenicillin was given as a single intravenous injection to 5 calves at a dose of $10 \mathrm{mg} / \mathrm{kg}$.

In a second experiment 6 calves were given five intramuscular injections of benzylpenicillin with $12 \mathrm{~h}$ interval. The dose was $10 \mathrm{mg} / \mathrm{kg}$. Two weeks later the same calves were given 3 intramuscular injections of procaine penicillin with an interval of $24 \mathrm{~h}$. The dose was $30 \mathrm{mg} / \mathrm{kg}$. All intramuscular injections were given in the neck. The cages had been in situ for at least 5 weeks when the experiments were performed.

\section{Sampling and analyses}

TCF was sampled by puncturing the skin and the unperforated part of the cage with a fine injection needle, the fluid was then aspirated with a $1 \mathrm{ml}$ syringe. Bleeding into the cage could be avoided by extreme care. Exactly $0.5 \mathrm{ml}$ was drawn from the same 2 cages (in the flanks) at each sampling time. The samples were pooled and stored in a refrigerator over night before analysis.

Blood was drawn from a jugular vein and was allowed to clot at room temperature before centrifugation. Serum was stored as the TCF samples before analysis. Serum and TCF samples were taken at times shown in Figs. $1-3$ and Table 1.

Penicillin G in serum and TCF was assayed by the agar well diffusion method using Sarcina lutea and Bacillus stearothermophilus var. calidolactis as test organisms.

Half-life, $t_{1 / q}$, for penicillin in serum was calculated from a semi-logarithmic plot of the concentration-time curve using the part of the curve where concentration decreased exponentially. In most cases the last four points were used. Half-life was calculated by the formula $\frac{\ln 2}{\beta}$, where $\ln 2$ is the natural logarithm of 2 and $\beta$ is the slope of the regression line calculated by the method of least squares (Baggot 1977). Area under curve (AUC) was calculated according to the trapezoidal rule. Student's t-test was used for statistical evaluation. The values given in text and figures are mean \pm standard error of the mean. 


\section{RESULTS}

The serum concentrations after a single intravenous and intramuscular injection are shown in Fig. 1. The first blood sample after intravenous injection was taken after $10 \mathrm{~min}$. At that time the mean was $23.56 \pm 3.27 \mu \mathrm{g} / \mathrm{ml}$. Half-time was $1.22 \pm 0.15 \mathrm{~h}$. The maximum level after intramuscular injection of benzylpenicillin, $9.55 \pm 0.85 \mu \mathrm{g} / \mathrm{ml}$, was reached after $30 \mathrm{~min}$. Thereafter the level declined, half-life was $1.42 \pm 0.08 \mathrm{~h}$. Significantly lower levels were obtained after procaine penicillin injection. The curve showed a plateau-profile with a maximum of $2.19 \pm 0.33 \mu \mathrm{g} / \mathrm{ml}$ after $4 \mathrm{~h}$. Half-time was $5.99 \pm 1.12 \mathrm{~h}$.

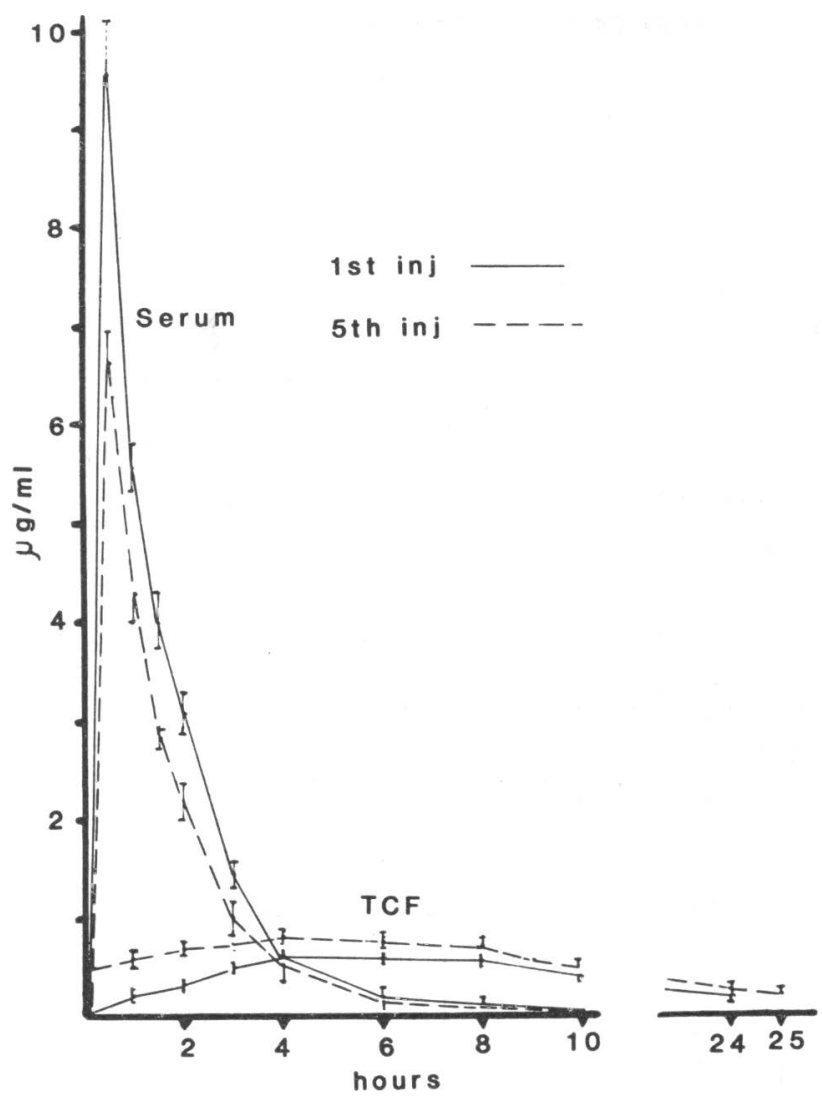

Figure 1. Serum concentrations of penicillin $G$ in calves after intravenous -. - and intramuscular injection of benzylpenicillin -...$(10 \mathrm{mg} / \mathrm{kg})$ and after intramuscular injection of procaine penicillin $(30 \mathrm{mg} / \mathrm{kg}) . \mathrm{n}=5, \overline{\mathrm{x}} \pm$ S.E.M. 


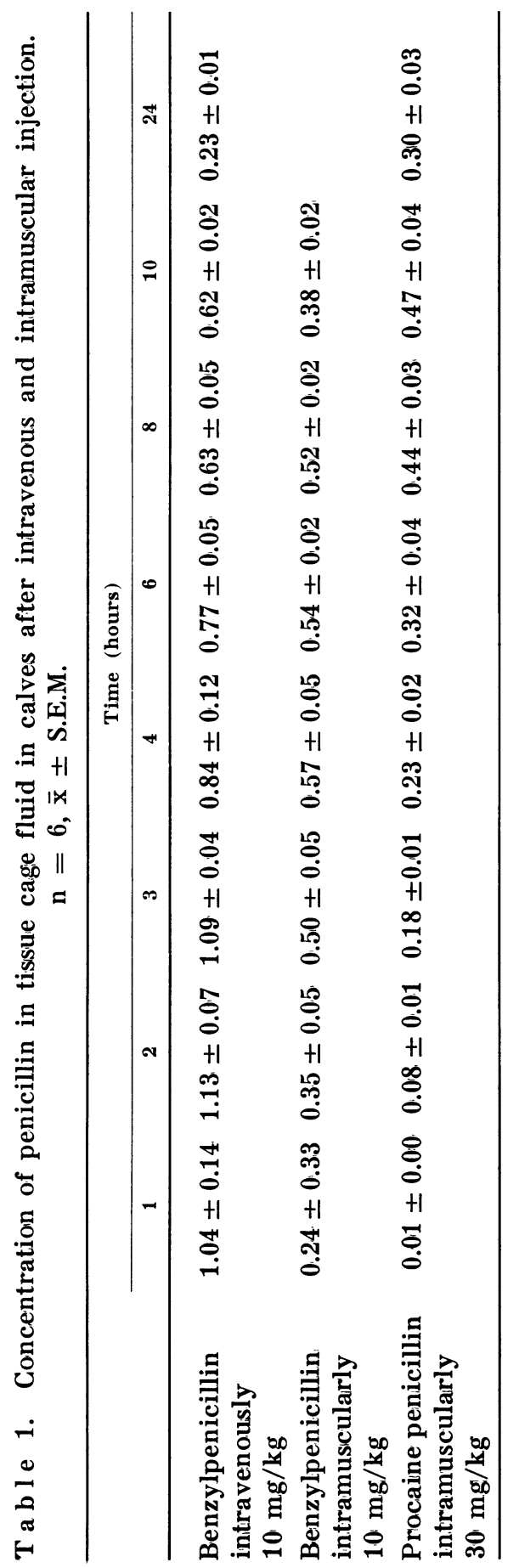


Area under curve from zero to infinity (AUC $\int_{0}^{\infty}$ ) was $13.64 \pm$ $1.95 \mu \mathrm{g} / \mathrm{ml} \cdot \mathrm{h}$, after intravenous injection and $15.20 \pm 0.61 \mu \mathrm{l} /$ $\mathrm{ml} \cdot \mathrm{h}$ after intramuscular injection. The value obtained after intravenous injection is however an underestimation as the first blood sample was taken after $10 \mathrm{~min}$. The largest $\mathrm{AUC}_{0} \int^{\infty}$, $26.59 \pm 0.50 \mu \mathrm{g} / \mathrm{ml} \cdot \mathrm{h}$, was obtained after injection of procaine penicillin.

The penicillin levels in TCF after single injections are shown in Table 1. The most rapid penetration occurred after intravenous injection of benzylpenicillin, while penetration was rather slow after procaine penicillin injection. Maximum values were reached after 2 and $10 \mathrm{~h}$, respectively. The maximum value after procaine penicillin, $0.47 \pm 0.04 \mu \mathrm{g} / \mathrm{ml}$, was less than $50 \%$ of that obtained after intravenous benzylpenicillin. Intramuscular injection of benzylpenicillin gave a maximum of $0.57 \pm 0.05 \mu \mathrm{g} / \mathrm{ml}$ after $4 \mathrm{~h}$.

Half-life in TCF could not be calculated because of the short sampling period. A comparison between AUC in serum and TCF for the first $10 \mathrm{~h}$ after the first intramuscular injections is given in Table 2. AUC $\int_{0}^{10}$ in serum was larger after procaine penicillin than after benzylpenicillin injection but $\mathrm{AUC}_{0} \int^{10}$ in TCF was significantly smaller.

The concentrations of penicillin in serum and TCF after repeated intramuscular injection are shown in Figs. 2-3. Maximum values in serum were obtained $20 \mathrm{~min}$ after the first

Table 2. Area under curve from zero to $10 \mathrm{~h}$ (AUC $\int_{0}^{10}$ ) in serum and tissue cage fluid (TCF) after intramuscular injection of penicillin G. $n=6, \bar{x} \pm$ S.E.M.

\begin{tabular}{lccc}
\hline & AUC $_{0} \int^{10} \frac{\mu g \cdot h}{\mathrm{ml}}$ & & TCF AUC $\left.\int_{0}\right]^{10}$ \\
\cline { 2 - 3 } & Serum AUG & TCF & \\
\hline $\begin{array}{l}\text { Procaine penicillin } \\
30 \mathrm{mg} / \mathrm{kg}\end{array}$ & $16.46 \pm 1.30$ & $2.61 \pm 0.21$ & $0.16 \pm 0.03$ \\
$\begin{array}{l}\text { Benzylpenicillin } \\
10 \mathrm{mg} / \mathrm{kg}\end{array}$ & $14.82 \pm 0.72$ & $4.99 \pm 0.10^{\star \star \star}$ & $0.30 \pm 0.01^{\star \star \star}$ \\
\hline$\star \star \star \mathrm{P}<0.001$ & & & \\
\hline
\end{tabular}




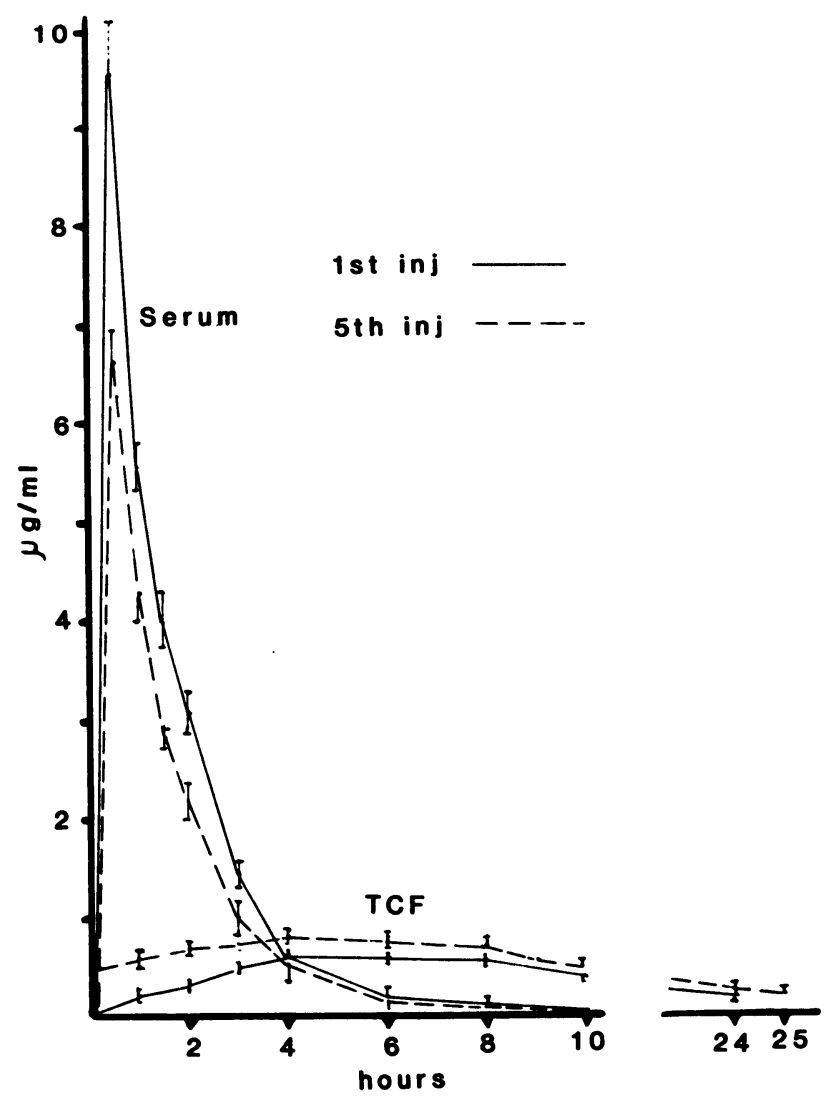

F i g u re 2. Concentrations of penicillin $\mathrm{G}$ in serum and tissue cage fluid (TCF) in calves after repeated intramuscular injections of benzylpenicillin $(10 \mathrm{mg} / \mathrm{kg})$. Injection interval $6 \mathrm{~h} . \mathrm{n}=6, \overline{\mathrm{x}} \pm$ S.E.M.

as well as after the fifth injection of benzylpenicillin, but the levels were significantly lower from 0.5 to $2 \mathrm{~h}$ after the fifth injection. (0.5-1.5 h:0.01<P<0.05; $2 \mathrm{~h}: 0.001<\mathrm{P}<0.01)$. As a consequence of the lower serum concentrations also AUC in serum was significantly lower after the last injection (Table 3).

There were no significant differences between the serum levels observed after the first and the third injection of procaine penicillin, but half-life was significantly shorter after the last injection (Table 3 ).

The serum level at the time of the last injection of benzylpenicillin was $0.04 \pm 0.02 \mu \mathrm{g} / \mathrm{ml}$, the level immediately before the last injection of procaine penicillin was $0.13 \pm 0.02 \mu \mathrm{g} / \mathrm{ml}$. 


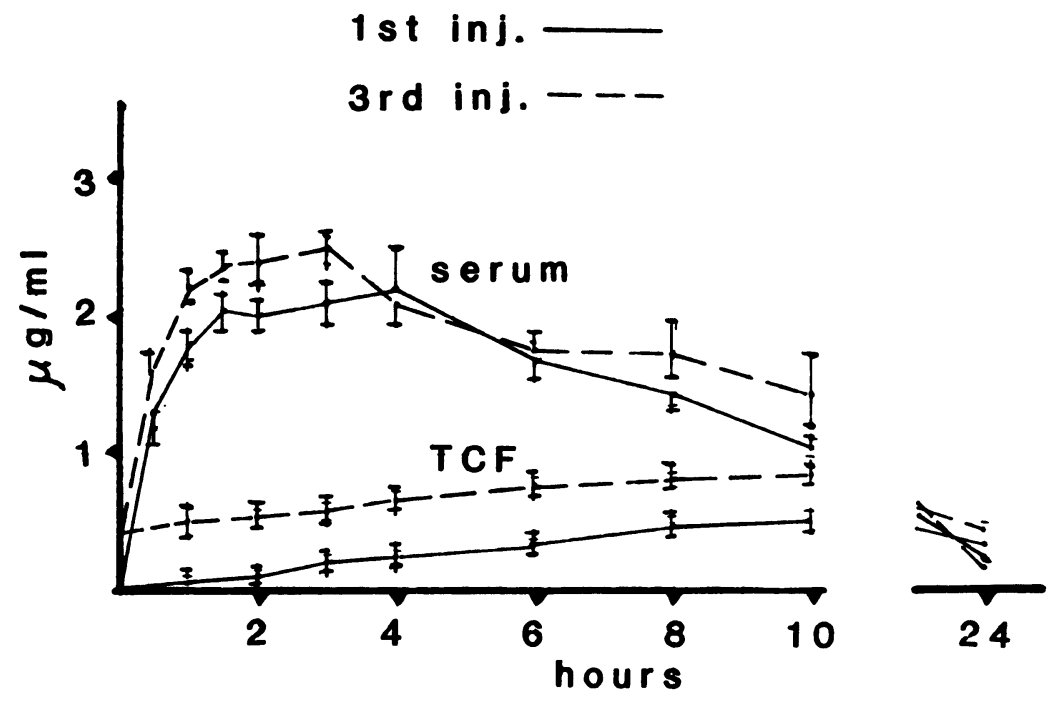

Fig u r e 3. Concentrations of penicillin $G$ in serum and tissue cage fluid (TCF) in calves after repeated intramuscular injections of procaine penicillin $(30 \mathrm{mg} / \mathrm{kg})$. Injection interval $24 \mathrm{~h} . \overline{\mathrm{x}} \pm$ S.E.M.

The concentration in TCF at the time of the fifth injection of benzylpenicillin was $0.50 \pm 0.04 \mu \mathrm{g} / \mathrm{ml}$ and $0.39 \pm 0.03 \mu \mathrm{g} / \mathrm{ml}$ before the third injection of procaine penicillin. The TCF levels after the last injections were significantly higher than after the first.

Table 3. Half-life ( $t / 2)$ and area under curve (AUC) of penicillin $\mathrm{G}$ after repeated intramuscular injection of penicillin $\mathrm{G}$. $\mathrm{n}=6, \overline{\mathrm{x}} \pm$ S.E.M.

\begin{tabular}{lcll}
\hline & $\mathrm{t} 1 / 2 \mathrm{~h}$ & $\mathrm{AUC}_{0} \int^{10} \frac{\mu \mathrm{g} \cdot \mathrm{h}}{\mathrm{ml}}$ & $\mathrm{AUC}_{0} \int^{24} \frac{\mu \mathrm{g} \cdot \mathrm{h}}{\mathrm{ml}}$ \\
\hline Benzylpenicillin a & & & \\
1st injection & $1.39 \pm 0.08$ & $14.82 \pm 0.72$ & \\
5th injection & $1.42 \pm 0.12$ & $11.07 \pm 0.53^{\star \star \star}$ & \\
Procaine penicillin $\mathrm{b}$ & & & \\
1st injection & $5.99 \pm 0.46$ & & $24.71 \pm 0.73$ \\
3rd injection & $3.98 \pm 0.22^{\star \star \star}$ & & $30.05 \pm 2.55$ \\
\hline
\end{tabular}

a Dose $10 \mathrm{mg} / \mathrm{kg}$, injection interval $12 \mathrm{~h}$

b Dose $30 \mathrm{mg} / \mathrm{kg}$, injection interval $24 \mathrm{~h}$ *** $\mathrm{P}<0.001$ 


\section{DISCUSSION}

All intramuscular injections were given in the lateral neck. According to Marshal \& Palmer (1980) injections in this region are seldom purely intramuscular, mainly because of the numerous small muscle fascicles. By using the dye crystal violet Marshal $\&$ Palmer showed that the injected solution could be found predominantly intermuscularly. The neck region was chosen in the present investigation as the intention was to study the serum levels of penicillin which occur after the injection technique used in Swedish field practice. Earlier studies (Luthman et al. unpublished) have shown that injection in the neck gives significantly higher serum peaks than injection in $\mathrm{m}$. triceps antibrachi.

The penicillin levels obtained in TCF were significantly lower than in serum, and the maximum levels were very delayed. This type of curve is typical for tissue cages with a small open area. Similar curves have been reported for various antibiotics by e.g. Waterman \& Kastan (1972), Chisholm et al. (1973, 1976), Holm et al. (1978), Ryan (1978), Stanton et al. (1982), Luthman et al. (1984). As described earlier cages with a very large open area, such as steel net cages, are difficult to use in cattle as they are completely filled with granulation tissue within a rather short period (Bengtsson et al. 1984).

In a very comprehensive investigation $Z i v$ et al. (1982) studied the penetration of selected antibiotics into TCF. The cage model was spherical with a diameter of $25 \mathrm{~mm}$ and an open area of up to $50 \%$. The peak of penicillin in TCF was found to be $57 \%$ of that in serum. Corresponding figure in our cage model was $6 \%$. The spheircal cage model is obviously more penetrable than that used in the present study, which may be partly explained by the finding of van Etta et al. (1983) that the ratio open area/ volume is one of the factors which determine penetration into TCF. Besides the shape of the cage there are other factors, which influence drug penetration. Síanton et al. (1982) described the importance of the sampling technique and Luthman et al. (1984) showed that the TCF levels sometimes varied with the time after implantation. It is thus difficult to compare results from different laboratories using different cage models and sampling techniques.

Similar curve profiles as obtained with the present cage model often occur in skin blister fluid (Schreiner et al. 1978). It seems 
however obvious that the cage is surrounded by a penetration barrier, since significantly higher serum concentrations of ampicillin was observed after subcutaneous injection than after injection of the same dose into the cage (Luthman et al.). A review of the various techniques developed for serial sampling of "interstitial fluid" was previously published by Barza (1981), who stated that the closest clinical counterparts to most tissue cage models are abscesses or nearly avascular foci. This statement is experimentally verified (Barza \& Weinstein 1974).

A major determinant for the extravascular distribution of drugs is the serum protein binding. Cars et al. (1984) compared the penetration of ampicillin and dicloxacillin into TCF in rabbits. The highly bound dicloxacillin $(98 \%)$ gave significantly lower levels in TCF than ampicillin (47\% bound). An intravenous injection of penicillin causes a high concentration of unbound drug, which obviously penetrates fairly rapidly into TCF (Table 1). It seems quite clear from Table 1 and Fig. 1 that high serum peaks of penicillin give higher concentrations in TCF than low sustained levels. Bengtsson et al. (1986) reported that AUC in TCF was related AUC in serum. The correlation was statistically significant. The results were obtained after intravenous and intramuscular injection of oxytetracycline. As shown in Table 2 there was no positive correlation between AUC in serum and TCF. Procaine penicillin gave larger AUC in serum than benzylpenicillin, but significantly smaller AUC in TCF.

The penicillin levels in serum and TCF after repeated intramuscular injections are shown in Figs. 2 and 3. The causes to the lower serum concentrations after the fifth injection of benzylpenicillin and the shorter half-life after the third procaine penicillin injection are dfificult to explain. As samples were taken only after the first and the last injections it is impossible to evaluate when these changes began. Sullins et al. (1984) made similar observation in horses, while Ziv et al. (1982) observed no changes of this kind after repeated penicillin injections in cattle. The shortening of the half-life and the lowering of the serum levels must have influenced the accumulation of penicillin in TCF. Without these changes the TCF levels should probably have been somewhat higher.

It is however of practical interest that a single intravenous injection gave higher levels in TCF than repeated intramuscular injections. When a high penicillin concentration is desirable in 
encapsulated foci the drug must be administered in a way that gives as high peak values as possible in serum. High serum peaks are easily achieved by intravenous injections, another way to increase the accumulation in such foci is intramuscular injections given with shorter intervals than in the present study.

\section{REFERENCES}

Adam, D., B. Reichart, J. Beyer, B. Kemke, B. Rothenfusser, C. Weinhold \& M. Helmerking: Diffusion of cefradine and cefalothin into interstitial fluid of human volunteers with tissue cages. Infection 1978, 6, Suppl. 1, 78-81.

Baggot, J. D.: Principles of Drug Disposition in Domestic Animals. W. B. Saunders Co. Philadelphia/London/Toronto 1977.

Barza, M. \& Weinstein: Penetration of antibiotics into fibrin loci in vivo. 1. Comparison of penetration into fibrin clots, abscesses and interstitial fluid. J. infect. Dis. 1974, 129, 59-65.

Barza, M.: Principles of tissue penetration of antibiotics. J. antimicrob. Chemother. 1981, 8, Suppl. C, 7-28.

Bengtsson, B., J. Luthman \& S. O. Jacobsson: Evaluation of a tissue cage model for use in cattle. Acta vet. scand. 1984, 25, 480-494.

Bergan, T.: Kinetics of tissue penetration. Scand. J. infect. Dis. 1978, Suppl. 1, 36-46.

Carbon, C., A. Contrepois, N. Brion \& S. Lamotte-Barrillon: Penetration of cefazolin, cephaloridin and cefamondole into interstitial fluid in rabbits. Antimicrob. Agents. Chemother. 1977, 11, 594598.

Cars, O., C. Henning \& S. E. Holm: Penetration of ampicillin and dicloxacillin into tissue cage fluid in rabbits: Relation to serum and tissue protein binding. Scand. J. infect. Dis. 1984, 13, 6974.

Chisholm, G. D., P. M. Waterworth, J. S. Calnan \& L. P. Garrod: Concentration of antibacterial agents in interstitial tissue fluid. Brit. med. J. 1973, 1, 569-573.

Chisholm, G. D., C. B. Smith, P. M. Waterworth \& J. S. Calnan: Factors influencing the distribution of antibacterial agents in interstitial tissue fluid: molecular size and protein binding. Infection, 4, suppl. 2, $123-127$.

Holm, S. E., C. Ekedahl \& A. M. Bergholm: Comparison of antibiotic assays using different experimental models and their possible clinical significance. Scand. J. infect. Dis. 1978, suppl. 14, $214-220$.

Luthman, J., B. Bengtsson \& S. O. Jacobsson: Penetration of antimicrobial agents into tissue cage fluid in cattle. Zbl. Vet. Med. A, 1984, 31, 303-313.

Marshal, A. B. \& G. B. Palmer: Injection sites and drug bioavailability. In: Trends in Veterinary Pharmacology and Toxicology. Ed. van Miert, A. S. J. P. A. M., J. Frens \& van der Kreek. Elsevier 
Scientific Publishing Comp. Amsterdam/Oxford/New York 1980.

Ryan, D. M.: Implanted tissue cages: A critical evaluation of their relevance in measuring tissue concentrations of antibiotics. Scand. J. infect. Dis. 1978, suppl. 13, 58-62.

Rylander, M., S. E. Holm, R. Norrby \& J. E. Brorson: Studies on the pharmacokinetics of cefoxitin, cefuroxime, cephaloridine and cephalothin using subcutaneous tissue cages. Scand. J. infect. Dis. 1978, 13, 52-57.

Schreiner, A., K. B. Hellum, A. Digranes \& I. Bergman: Transfer of penicillin $G$ and ampicillin into human skin blisters induced by suction. Scand. J. infect. Dis. 1978, suppl. 14, 233-237.

Sullins, K., N. T. Messer \& L. Nelson: Serum concentrations of penicillin in the horse after repeated intramuscular injections of procaine penicillin $G$ alone or in combination with benzathine penicillin and/or phenylbutazone. Amer. J. vet. Res. 1984, 45, 1003-1007.

Stanton, A., R. J. Bywater \& G. H. Palmer: The use of tissue cages in calves to study distribution of antibiotics in interstitial fluid. Proc. 2nd Conf. European Assoc. Vet. Pharmacol. Toxicol.. Toulouse 1980.

Taylor, A. \& H. Gibson: Concentrating ability of lymphatic vessels. Lymphology 1975, 8, 43-49.

Tight, R. R. \& A. C. White: Serum and subcutaneous chamber dynamics of penicillins after single large parenteral doses. Antimicrob. Agents Chemother. 1980, 17, 229-234.

van Etta, L., C. E. Fasching, L. R. Peterson \& D. N. Gerding: Comparison study of the kinetics of ceftizoxime penetration into extravascular spaces with known surface area/volume ratio in vitro and in vivo in rabbits. Antimicrob. Agents Chemother. $1983,23,49-53$.

Waterman, N. G. \& L. B. Kastan: Interstitial fluid and serum antibiotic concentrations. Arch. Surg. 1972, 105, 192-196.

Ziv, G., M. Wanner \& J. Nicolet: Distribution of penicillin G, dihydrostreptomycin, oxytetracycline, and chloramphenicol in serum and subcutaneous chamber fluid. J. vet. Pharmacol. Therap. $1982,5,59-69$.

\section{SAMMANFATTNING}

Distribution av penicillin $i$ serum och vävnadskammarvätska hos kalv

Koncentrationerna av penicillin i serum och vävnadsvätska uppsamlad med hjälp av vävnadskammare studerades hos kalv. Intravenös injektion gav mycket högre koncentrationer $i$ vävnadskammare än intramuskulär. Penetrationen till kammarvätskan skedide mycket långsamt efter injektion av prokainpenicillin. Resultaten visade att höga koncentrationstoppar $i$ serum har en avgörande betydelse för penetrationen till kammarvätskan. Upprepade intramuskulära injektioner gav en ackumulation av penicillin i kamrarna. Lika höga koncentra- 
tioner kunde dock uppnås efter en enda intravenös injektion. Den kilniska motsvarigheten til vävnadskammare är abscesser. Det konkluderades att när höga penicillinkoncentrationer är önskvärda i svårtillgängliga infektionsfoci bör penicillin tillföras på ett sådant sätt att högsta möjliga serumkoncentrationer uppnås.

(Received March 24, 1986).

Reprints may be requested from: J. Luthman, the Department of Cattle and Sheep Diseases, College of Veterinary Medicine, Swedish University of Agricultural Sciences, S-750 07 Uppsala, Sweden. 